\title{
North to Alaska: Spawning by Market Squid, Doryteuthis opalescens, in Subarctic Waters
}

\author{
JOHN H. EILER
}

North to Alaska, go north the rush is on!

(Johnny Horton, 1960's country western singer).

\section{Introduction}

Over the last several decades, changes have occurred worldwide in the physical nature of the marine environment (Duarte, 2014). In the North Pacific, this has been characterized by a general warming trend throughout the region (Litzow et al., 2020; Cheng et al., 2020). Similar to the lyrics of the song, this trend has been accompanied by the migration of a number of southern species into subarctic and Arctic waters, ranging from primary producers to apex predators (Pearcy and Schoener, 1987; Venrick et al., 1987; Mueter and Litzow, 2008; Spies et al., 2019).

Market squid, Doryteuthis opalescens, are a small Myopsid squid that inhabit nearshore waters along the $\mathrm{Pa}$ cific coast of North America. Although this species has been reported from Baja California to southeast Alaska, it is most abundant in the southern portion of its range (from Baja to central

John H. Eiler is with the Auke Bay Laboratories, Alaska Fisheries Science Center, National Marine Fisheries Service, NOAA, Juneau, Alaska 99801 (john.eiler@noaa.gov).

doi: https://doi.org/10.7755/MFR.83.1-2.1
California) and is an important commercial species in fisheries along the California coast (CDFG, 2005; Zeidberg et al., 2006). Market squid are also prey for many predators, including various fish, sea birds, and marine mammals. Spawning typically extends into southern British Columbia (Vojkovich, 1998; DFO, 1999; CDFG, 2005), although it has occasionally been reported in Queen Charlotte Strait in northern British Columbia (Bernard, 1980) and as far north as southeast Alaska (Wing and Mercer, 1990). In this paper, I document a recent increase in abundance and repeated spawning events by market squid in southeast Alaska and examine environmental factors that might be influential.

\section{Methods}

Since the mid-1930's, biologists have been monitoring marine life and ocean conditions at the NMFS Little Port Walter research station in southeast Alaska (Fig. 1). Little Port Walter (LPW) is a small saltwater bay (about $1.5 \mathrm{~km}$ long with a maximum width of $0.4 \mathrm{~km}$ ) that empties into southern Chatham Strait approximately $30 \mathrm{~km}$ from the Gulf of Alaska. The bay consists of two sections, commonly referred to as the inner and outer bay, separated by a narrow peninsula. The inner bay is characterized by a relatively flat muddy bottom with a maximum depth of $21 \mathrm{~m}$. The outer bay consists of a rocky, steep-sided basin with a maximum depth of $50 \mathrm{~m}$. Fresh water flows into the inner bay from Sashin Creek which drains a forested watershed of about $13 \mathrm{~km}^{2}$, with flows ranging from 0.02 to $75.0 \mathrm{~m}^{3} / \mathrm{s}$ (Olson and McNeil, 1967).

A variety of marine life inhabits the area. Local fishermen harvest Pacific salmon, Oncorhynchus spp.; halibut, Hippoglossus stenolepis; sablefish, Anoplopoma fimbria; rockfish, Sebastes spp.; and other marine species. Forage fish, including Pacific herring, Clupea pallasii; and capelin, Mallotus villosus, are frequently seen in nearshore waters. Various marine mammals also frequent the area, including humpback whales, Megaptera novaeangliae; Steller sea lions, Eumetopias jubatus; and harbor seals, Phoca vitulina. Piscivorous sea birds are often present during the summer, including double-crested cormorants, Phala-
ABSTRACT-Market squid, Doryteuthis opalescens, inhabit nearshore waters along the Pacific coast of North America from Baja California to southeast Alaska, with spawning typically ranging as far north as southern British Columbia. Increased numbers of market squid and successive spawning events were observed during 2015-19 in Little Port Walter, a small saltwater bay in southeast Alaska. These observations suggest a recent shift in distribution and, combined with evidence from the 1980's, suggest that spawning periodically extends into subarctic waters. The timing (mid-June to early July) was relatively compressed compared to spawning by southern populations. Water temperature during this period averaged $10.0^{\circ} \mathrm{C}$ and was within the lower range reported for this species during spawning. Salinity was less than normally observed, averaging 31.1 ppt. Environmental factors within the area have not changed appreciably since the late 1990's-early 2000's, suggesting that the infrequent observations of mar- ket squid and absence of spawning prior to 2015 were not related to local conditions. It is unclear whether the increased abundance and repeated spawning events by market squid over the last several years represent the development of an established population within southeast Alaska or is the result of continued immigration from areas farther south, although colder water temperatures along the outer coast during 2017-18 were probably less conducive to northerly movements by this species. 


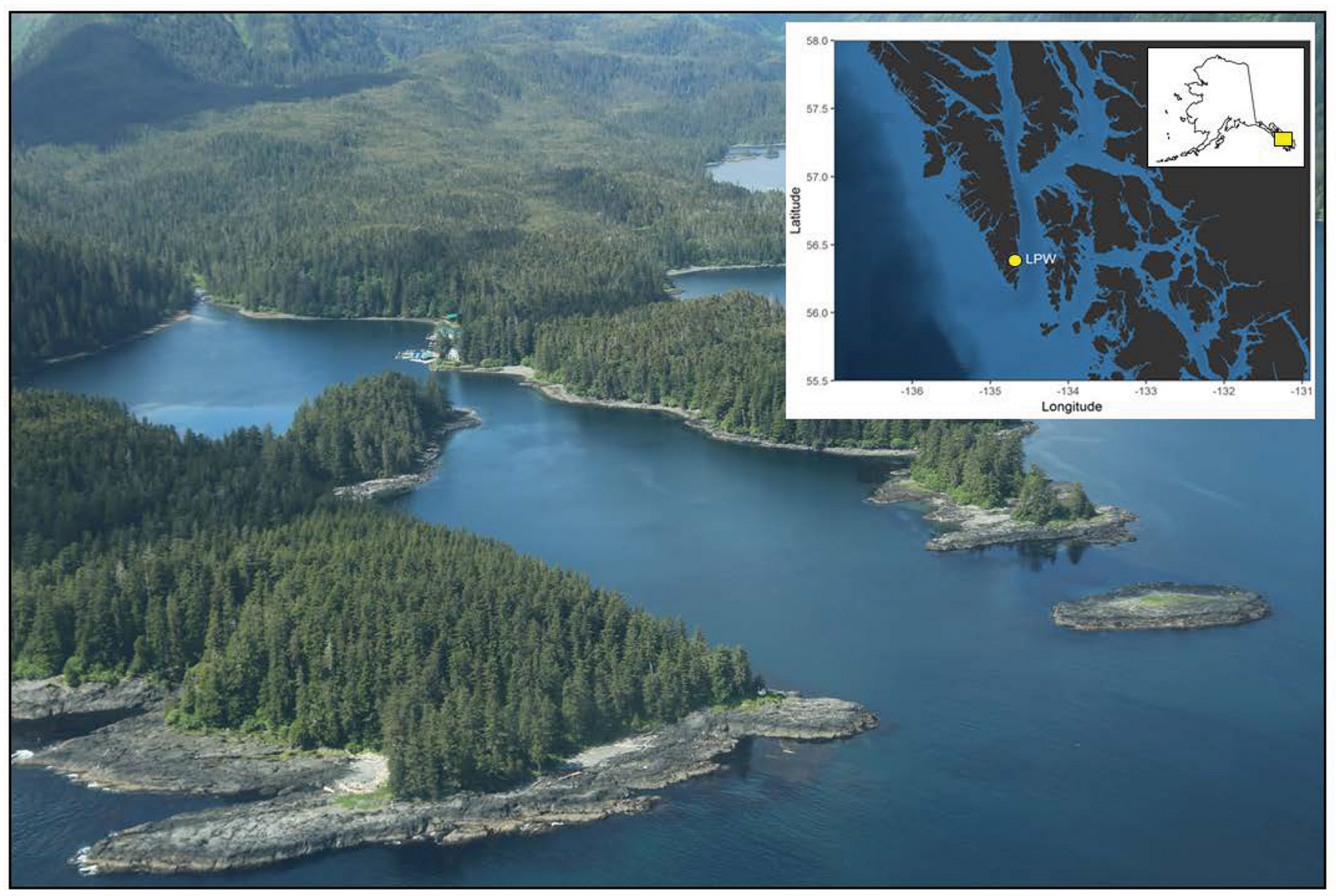

Figure 1.-Little Port Walter located near the southern tip of Baranof Island in southeast Alaska.

crocorax auritus; yellow-billed loons, Gavia adamsii; and various sea ducks, Anatidae.

Year-round observations are made at the station by the research staff and visiting scientists. Environmental data on marine conditions (including water temperature, salinity, and $\mathrm{pH}$ ) are recorded daily at a depth of $2 \mathrm{~m}$ from a standardized location using a multiparameter meter $^{1}$. Daily meteorological information is also collected at the station, including air temperature and precipitation. Satellite-based sea surface temperature data (source: NOAA Coral Reef Watch Program) were accessed via the NOAA CoastWatch

${ }^{1}$ Model Professional Plus, YSI, Yellow Springs, $\mathrm{OH}$. Mention of trade names or commercial firms does not imply endorsement by the National Marine Fisheries Service, NOAA.
West Coast Node ERDDAP server ${ }^{2}$ and used to assess temperature patterns off the coast of southeast Alaska. Average daily temperatures during 1986-2019 were compiled for coastal waters near the entrance to Chatham Strait (from lat. $55.8^{\circ} \mathrm{N}$, long. $-135^{\circ} \mathrm{W}$ to lat. $55.5^{\circ} \mathrm{N}$, long. $-136^{\circ} \mathrm{W}$ ), and averaged for each year.

Pacific salmon and other marine fish are caught during the summer using various capture methods. Since the late 1980 's, a floating fish trap (similar to the type described by Hipkins, 1968) has been deployed in the inner bay and used as the primary method for capturing adult Chinook salmon, O. tshawytscha, returning to a research hatchery at the station. The trap, a series of mesh enclosures (outer heart,

${ }^{2}$ https://coastwatch.pfeg.noaa.gov/erddap/griddap/NOAA_DHW.html. inner heart, and pot) ranging in size from $12 \mathrm{~m} \times 12 \mathrm{~m}$ to $6 \mathrm{~m} \times 6 \mathrm{~m}$ with a depth of $6 \mathrm{~m}$ and $2.5 \mathrm{~cm}$ square mesh, is attached to the station's floating walkway (which runs parallel to the shoreline). A mesh lead (45 m long) extends from the entrance of the trap to the shore. Fish that encounter the lead, follow it into the trap and congregate in the pot where they are crowded together and removed. The trap is monitored daily (more frequently when large numbers of fish are present) from early June to late August, and removed in early September. In addition to specific research projects, the presence of predators and atypical marine life observed within LPW are recorded year round.

\section{Results}

Over the years, small numbers of market squid have been sporadically 




Figure 2.-Market squid and squid egg cases observed during 2015-19 in Little Port Walter, southeast Alaska.

reported in LPW. A significant change occurred in 2015 when I observed several hundred squid swimming in and out of the fish trap. The squid moved freely through the mesh netting of the trap, making it impossible to capture and enumerate the entire school. Long-handled dip nets were used to collect a small sample for identification purposes. In addition to the substantial increase in numbers, the squid were also laying clusters of egg cases on the netting of the trap (Fig. 2). Schools of market squid and subsequent spawning events (based on the presence of egg cases) were observed during 2016-19. Most of the squid were present from mid-June to midJuly, with scattered individuals recorded as late as mid-August.

Although I did not directly observe squid spawning, egg cases were laid from mid-June (as early as June 16 in 2015 ) to early July (as late as July 4 in 2019). Four to six clusters were observed annually, ranging in depth from $\sim 2-4 \mathrm{~m}$. Neither squid nor evidence of spawning were observed during the fall and spring even though research activities continued and mesh holding pens $(6 \mathrm{~m} \times 6 \mathrm{~m} \times 6 \mathrm{~m})$ were being used in the inner bay. Hatching was not observed during the study and no paralarvae were seen, although plankton blooms during the summer limit visibility and no additional sampling (e.g., plankton tows) was conducted. Several egg cases, examined when the fish trap was disassembled in the fall, were covered with algae and had not hatched.

Environmental data on marine conditions in LPW collected $\sim 50 \mathrm{~m}$ from the fish trap showed that saltwater temperatures from mid-June to midJuly averaged $10.0^{\circ} \mathrm{C}\left(\mathrm{SD}=0.3^{\circ} \mathrm{C}\right)$ during 2015-19 and displayed a similar seasonal pattern (Fig. 3). Comparable patterns were observed during 1998-2014 (Fig. 4), with temperatures averaging $9.9^{\circ} \mathrm{C}\left(\mathrm{SD}=0.5^{\circ} \mathrm{C}\right)$. Annual mean temperatures during 1998 2019 were similar among years, averaging $7.7^{\circ} \mathrm{C}\left(\mathrm{SD}=0.4^{\circ} \mathrm{C}\right)$. Conversely, annual mean sea surface temperatures off the outer coast of southeast Alaska during 1986-2019 were more variable, with notable increases during 2004-05 and 2015-16 (Fig. 5).

Minimal differences were also observed for the other environmental data collected at the station. Salinity during June and July averaged 31.1 parts per thousand $(\mathrm{ppt})(\mathrm{SD}=0.6 \mathrm{ppt})$ during 2016-19 (Fig. 6). Information was not available for this period during 2015, but salinity during late July and August was similar to subsequent years. Although limited $\mathrm{pH}$ data are available, levels from mid-June to mid-July averaged $8.0(\mathrm{SD}=0.6)$ during 2014-19.

\section{Discussion}

Although market squid have been previously reported in southeast Alas- $\mathrm{ka}$, the increased numbers and successive spawning events observed in LPW over the last several years indicate a northerly shift in distribution and, combined with other evidence, suggests that spawning periodically extends into subarctic waters, likely triggered by changing conditions in the marine environment.

Major changes have occurred in the North Pacific over the last 50 years, including periodic El Niño and La Niña events, decadal regime shifts, and irregular inter-annual variation in marine conditions (Mantua et al., 1997; Portner, 2008; Peterson et al., 2015). During late 2013, a large, unprecedented mass of anomalously warm water (commonly referred to as the Blob) began forming in the North Pacific. This formation, sustained by an El Niño event during 2015-16, dominated much of the Gulf of Alaska over the next several years, with temperatures in some areas greater than $3^{\circ} \mathrm{C}$ above long-term averages (Peterson et al., 2015; Tseng et al., 2017).

Although these events did not appear to influence marine conditions in LPW, the influx of warm water along the outer coast may have prompted the northward migration of market squid by creating a thermally-acceptable avenue into southeast Alaska. Market squid began appearing in surface trawls along the outer coast dur- 


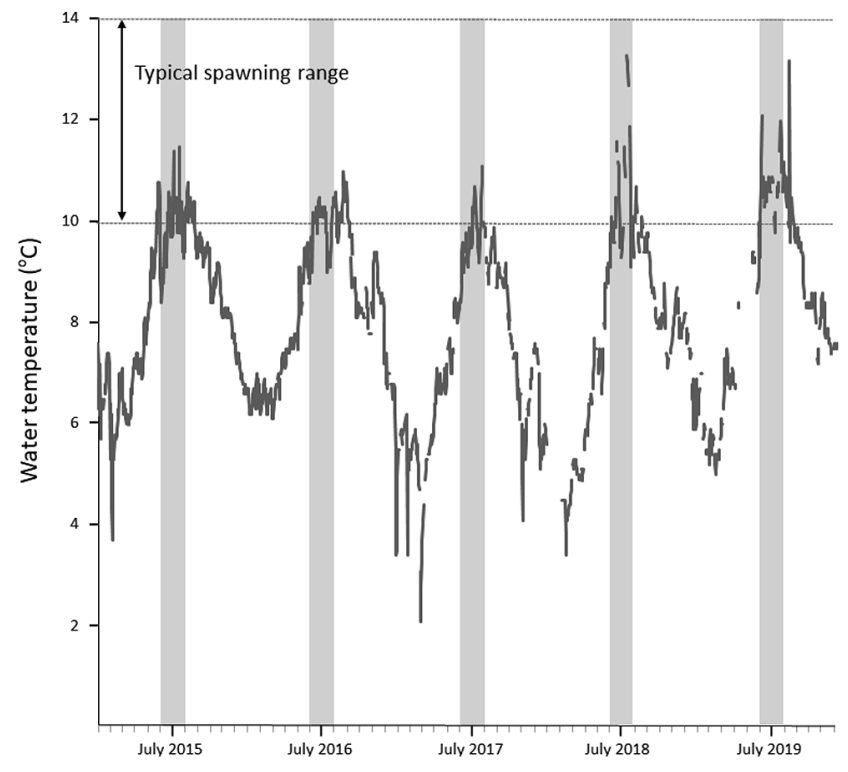

Figure 3.-Daily saltwater temperatures during 2015-19 in Little Port Walter, southeast Alaska. The monthly periods when market squid were observed (shaded gray) and the typical temperature range associated with spawning by this species (Zeidberg et al., 2011) are shown.

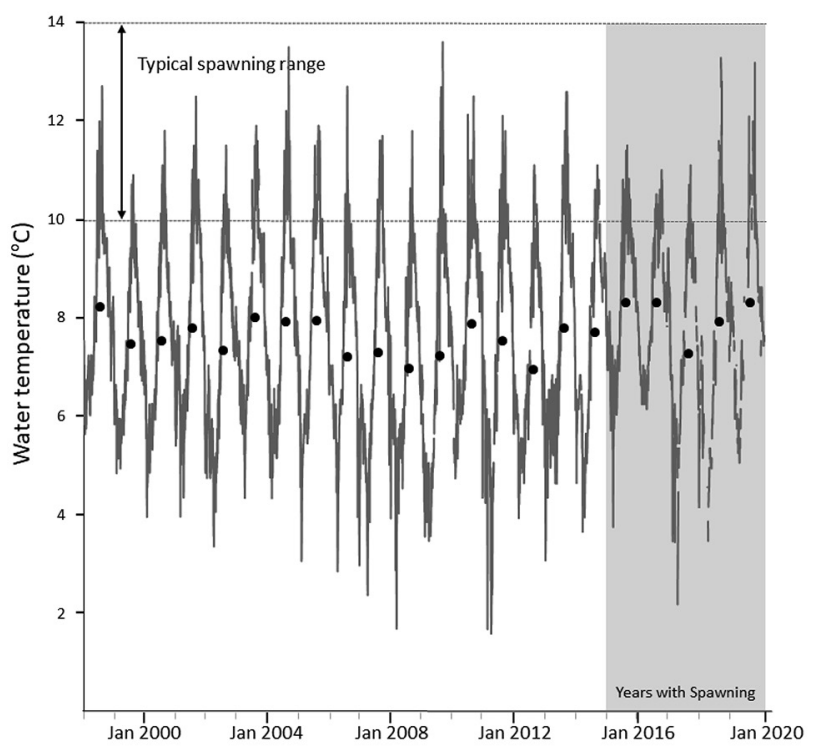

Figure 4.-Daily saltwater temperatures during 1998-2019 in Little Port Walter, southeast Alaska. Annual mean temperatures (black dots) are also shown. The years when market squid were observed (shaded gray) and the typical temperature range associated with spawning by this species (Zeidberg et al., 2011) are indicated. ing 2016 and $2017\left(\mathrm{Moss}^{3}\right)$. Although small numbers of market squid have been sporadically observed in bottom trawl surveys as far west as the Shumagin Islands, several hundred were captured off the coast of southeast Alaska during 2017 (AFSC, 2020). Local fishermen in southeast Alaska have also reported catching increased numbers of market squid in recent years (FIS, 2017; Navarro, 2018).

Similar patterns have been previously reported. Market squid were abundant in coastal waters of southeast Alaska during major El Niño events in 1957-58 and the early 1980's based on stomach contents from troll-caught salmon (Reid, 1961; Wing, 1985), with sightings observed as far north as Cross Sound (lat. $58^{\circ} \mathrm{N}$ ). There is also evidence that spawning has previously occurred within the area. Large schools of market squid harvested off the western coast of Baranof Island during 1982

${ }^{3}$ Moss, J. National Marine Fisheries Service, AFSC, Auke Bay Lab., 17109 Pt. Lena Loop Road, Juneau, AK 99801 Personal commun. included sexually mature individuals, and several egg case clusters were reported in a small bay on Kuiu Island (Wing and Mercer, 1990), located about $40 \mathrm{~km}$ northeast of LPW.

Market squid spawn year-round depending on their location (Fields, 1965). Most spawning occurs from April to October in central California, and from October to May in the southern part of the state (Zeidberg et al., 2006). In southern British Columbia, spawning generally occurs between December and September, with two distinct peaks in March and July (DFO, 1999). By comparison, the timing exhibited by market squid in LPW was relatively discrete, ranging from mid-June to early July.

Based on the environmental data collected at the site, the compressed timing was likely related to water temperature. Zeidberg et al. (2011) reported that $12^{\circ} \mathrm{C}$ was the optimal temperature for this species, with spawning typically occurring between $10^{\circ} \mathrm{C}$ and $14^{\circ} \mathrm{C}$; spawning was not observed in water colder than $7.5^{\circ} \mathrm{C}$. Water tem- peratures in LPW were within this range when market squid were present and egg clusters observed (June and July), whereas temperatures from September to May were typically below this threshold.

Conversely, salinity in LPW during May-July was less than normally observed for this species, with levels within the lower range for saltwater (typically designated as 30-40 ppt, Elliot and McLusky, 2002), likely due to the infusion of fresh water from Sashin Creek. Whereas, California fishermen reported that spawning aggregations of market squid dispersed at the first sign of fresh water (Zeidberg, 2013).

Summer conditions in LPW during 2015-19 were comparable to those in 1998-2014. These similarities suggest that the sporadic observations of market squid and absence of spawning prior to 2015 were not related to local conditions.

In addition to spawning, the survival of the resulting progeny (and the related persistence of local populations) 


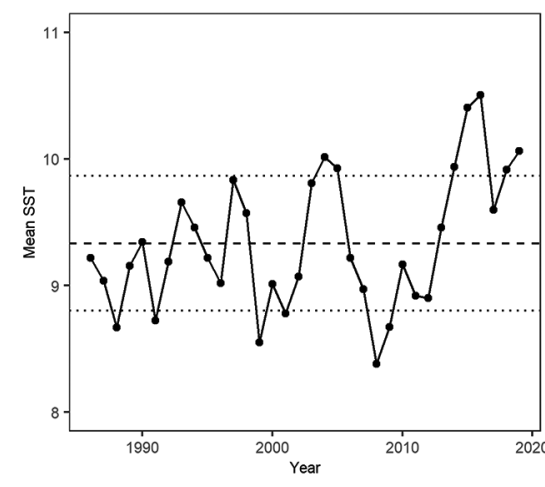

Figure 5.-Annual mean sea surface temperatures (SST) in marine waters off the coast of southeast Alaska near the mouth of Chatham Strait during 1986-2019. The horizontal dashed line represents the overall mean of the annual time series and the dotted lines represent one standard deviation around the mean.

is also dependent on the conditions associated with summer foraging, juvenile growth, and overwintering. Navarro et al. (2018) reported that although the temperature range for spawning market squid in coastal areas of southern California was fairly broad (from $9.9^{\circ} \mathrm{C}$ to $15.5^{\circ} \mathrm{C}$ ), egg deposition was limited to areas with high dissolved oxygen $\left(>160 \mathrm{mmol} \mathrm{kg}^{-1}\right)$ and $\mathrm{pH}>7.8$, and that these factors likely influenced habitat suitability. The $\mathrm{pH}$ levels recorded in LPW were within this range. Data are not available for dissolved oxygen; however, levels were probably suitable due to the regular wave and tidal action within the inner bay combined with the infusion of highly-oxygenated water from Sashin Creek.

It is not known whether the spawning events in LPW produced viable offspring. No juvenile life stages were seen during the study, although conditions for in situ observations were not ideal. Egg cases transported from LPW to the Auke Bay Laboratories (Juneau, Alaska) and held in $16^{\circ} \mathrm{C}$ water hatched and continued to develop for several months. ${ }^{4}$ Juvenile life stag-

\footnotetext{
${ }^{4}$ https://www.adn.com/fishing/article/couldmarket-squid-become-new-southeast-fishery/2015/12/02/
}

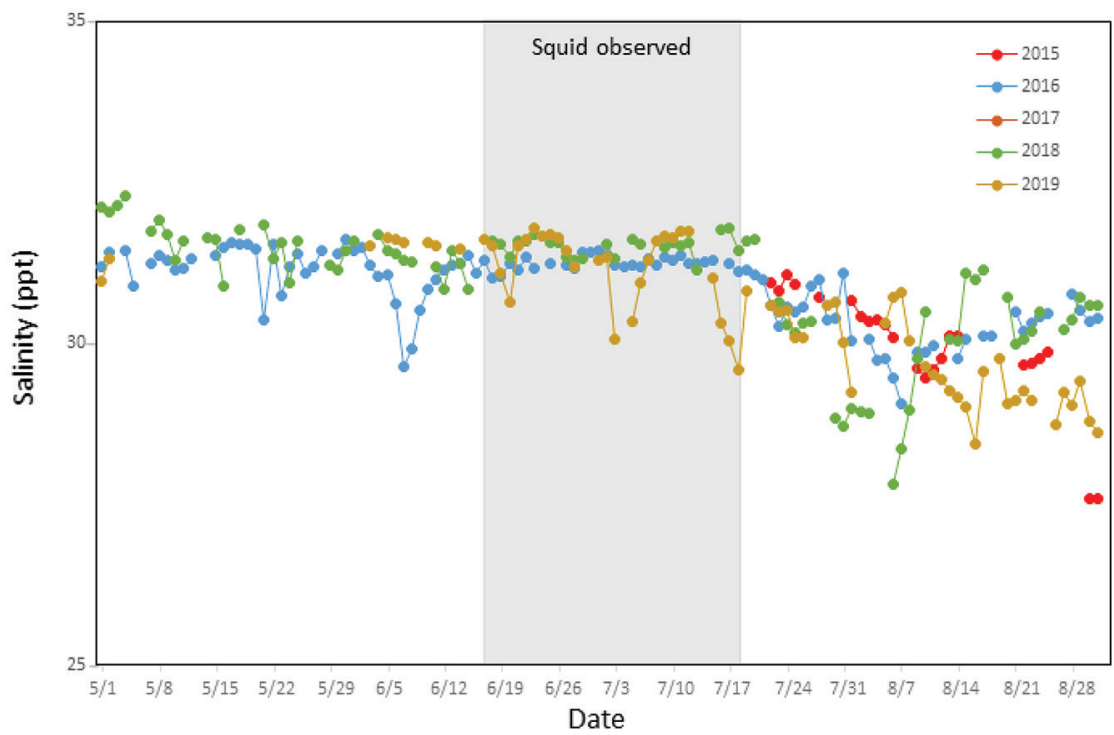

Figure 6.-Daily salinity from May through August during 2015-19 in Little Port Walter, southeast Alaska. The period when market squid were observed (shaded gray) is shown.

es were reported in samples from Baranof Island in July and August 1982 (Wing and Mercer, 1990), suggesting that localized spawning during that year may have been successful.

After becoming sexually mature, market squid typically form large schools in sheltered bays and inlets (Macewicz et al., 2004). The squid usually congregate for up to two weeks prior to spawning, even though these aggregations are highly susceptible to predation. Spawning typically occurs at night, although some diurnal activity has been reported (Forsythe et al., 2004; Zeidberg et al., 2012). Once spawning begins, egg deposition is highly synchronous, typically occurring within $24 \mathrm{~h}$ (Perretti et al., 2016). Macewicz et al. (2004) estimated that squid were active on spawning grounds for less than a week with most eggs deposited during the first day. Similar patterns were observed in LPW. Schools of squid were only present for a limited time. Squid were not observed actively spawning during daylight hours, and evidence of spawning was based solely on the presence of egg case clusters, which appeared to be laid concurrently.

Market squid typically deposit egg cases on soft, sandy substrates at depths of 20-70 m (Fields, 1965; Zeidberg et al., 2012). In contrast, the bottom of the LPW inner bay is composed primarily of fine silt and organic sediment. No directed surveys were conducted within the surrounding area, and it is not known if squid were laying eggs at other sites within the bay or congregating in nearby areas.

Zeidberg et al. (2012) reported that although $90 \%$ of the clusters they located in California were on sand, egg cases were also attached to hard surfaces, and the rocky substrate of the outer bay and along the periphery of the inner bay may provide suitable sites for egg deposition. The congregation of squid around the LPW fish trap may relate to predator avoidance. Adult salmon are present in LPW from mid-June to late September, and the trap may provide structure and some measure of protective cover. On several occasions, the squid moved out of the trap (through the netting) when Chinook salmon entered and returned after the fish had been removed.

Market squid have a relatively short life span and are semelparous, dying shortly after spawning. Growth estimates based on length-frequency anal- 
ysis initially suggested a life span of several years (Fields, 1965; Bernard, 1980). Spratt (1978) used statolith aging to refine age estimates and reported that market squid in central California spawned between one and two years of age.

However, more recent studies using this approach suggested that earlier assessments overestimated longevity (Jackson, 1998). Based on these findings, Butler et al. (1999) reported that the life span of market squid harvested in southern California fisheries ranged from 6 mo to $<250$ days, suggesting a pattern of semiannual spawning. Jackson and Domeier (2003) observed a similar pattern, but they reported that maturation was highly dependent on ocean conditions. The synchronous timing of spawning in LPW (JuneJuly) over several years suggests either a self-replicating population with individuals maturing at about one year of age, undocumented spawning within the area at other times of the year (although marine temperatures may not be suitable based on information reported by Zeidberg et al., 2011), or immigration from other areas.

It is unclear whether the repeated spawning by market squid in LPW represents the development of an established population or is the result of continued immigration from areas farther south. It has been estimated that market squid can potentially travel as much as $500 \mathrm{~km}$ during the course of their life (Zeidberg, 2013), suggesting that squid from populations in northern British Columbia could be continuing to move into southeast Alaska. However, market squid were observed in LPW during 2018-19 despite the demise of the Blob and the incursion of a cold water La Niña event in the Gulf of Alaska during 2017-18. Based on past information, colder temperatures along the outer coast may be less conducive to the northward movement of southern stocks. If so, the continued presence of market squid in LPW may indicate that a self-sustaining population has been established within the area. Expanded surveys and genetic sampling would be instrumental in addressing this hypothesis.

Due to the rapid turnover and short generation time exhibited by this species, annual recruitment is essential to maintain local populations. This dynamic also increases the vulnerability of market squid populations to changing conditions in the marine environment. The general absence of market squid in southeast Alaska from the early 1980's to 2015 suggests that these populations are ephemeral and reflect large-scale changes in marine conditions.

\section{Acknowledgments}

I thank R. Bare, G. Foley, B. Malessa, A. Marinelli, and S. Ransbury for their assistance on this project. J. Watson compiled offshore temperature data and created the accompanying figure. The manuscript was critically reviewed by E. Farley, A. Gray, J. Murphy, E. Yasumiishi, and three anonymous referees. The findings and conclusions in the paper are those of the author and do not necessarily represent the views of the National Marine Fisheries Service, NOAA. Reference to trade, firm, or product names is for descriptive purposes only and does not imply endorsement by the National Marine Fisheries Service, NOAA.

\section{Literature Cited}

AFSC. 2020. AFSC/RACE/GAP: RACEBASE database from 2010-06-15 to 2010-08-15. NOAA National Centers for Environ. Info. (avail. at https://inport.nmfs.noaa.gov/inport/ item/22008).

Bernard, F. R. 1980. Preliminary report on the potential commercial squid of British Columbia. Can. Tech. Rep. Fish. Aquat. Sci. 942, 51 p.

Butler, J., D. Fuller, and M. Yaremko. 1999. Age and growth of market squid (Loligo opalescens) off California during 1998. Calif. Coop. Oceanic Fish. Invest. Rep. 40:191-195 (avail. at http://calcofi.org/ publications/calcofireports/v40/Vol_40_Butler_etal.pdf).

CDFG. 2005. Background: a description of the species, the fishery, and social and economic components of the market squid fishery. In Final Market Squid Fishery Management Plan, p. 18-56. Calif. Dep. Fish Game, Sacramento.

Cheng, L., J. Abraham, J. Zhu, K. E. Trenberth, J. Fasullo, T. Boyer, R. Locarnini, B. Zhang, F. Yu, L. Wan, X. Chen, X. Song, Y. Liu, and M. E. Mann. 2020. Record-setting ocean warmth continued in 2019. Adv. Atmos. Sci.
37:137-142 (doi: https://doi.org/10.1007/ s00376-020-9283-7).

DFO. 1999. Opal squid. DFO Sci. Stock Status Rep. C6-04. Dep. Fish. Oceans Can., 3 p. (avail. at https://publications.gc.ca/collections/collection_2016/mpo-dfo/Fs76-1-C604-1999-eng.pdf)

Duarte, C. M. 2014. Global change and the future ocean: a grand challenge for marine sciences. Front. Mar. Sci. 2, 63 p. (doi: https:// doi.org/10.3389/fmars.2014.00063).

Elliot, M., and D. S. McLusky. 2002. The need for definition in understanding estuaries. Estuarine Coast. Shelf Sci. 55:815-827 (doi: https://doi.org/10.1006/ecss.2002.1031).

Fields, W. G. 1965. The structure, development, food relations, reproduction, and life history of the squid, Loligo opalescens Berry. Calif. Dep. Fish Game, Fish Bull. 131, 108 p.

FIS. 2017. Alaska considers squid fishery development proposal. Fish Inform. Serv. (avail. at http://www.fis-net.com/fis/worldnews/worldnews.asp monthyear $=\&$ day $=19 \& \mathrm{id}=95268 \& 1$ $=e \&$ special $=0 \& n d b=0$ ).

Forsythe, J., N. Kangus, and R. T. Hanton. 2004 Does the California market squid (Loligo opalescens) spawn naturally during the day or at night? A note on the successful use of ROVs to obtain basic fisheries biology data. Fish. Bull. 102:389-392 (avail. at https:// spo.nmfs.noaa.gov/sites/default/files/pdf-content/2004/1022/forsythe.pdf).

Hipkins, F. W. 1968. Construction and operation of a floating Alaska salmon trap. Bur. Commer. Fish., Fish. Leaflet 611, 12 p.

Jackson, G. 1998. Research into the life history of Loligo opalescens: where to from here? Calif. Coop. Oceanic Fish. Invest. Rep. 39:101-107 (avail. at http://calcofi.org/publications/calcofireports/v39/Vol_39_Jackson.pdf)

Jackson, G. D., and M. L. Domeier. 2003. The effects of an extraordinary El Niño / La Niña event on the size and growth of the squid Loligo opalescens off Southern California. Mar. Biol. 142:925-935 (doi: https://doi. org/10.1007/s00227-002-1005-4)

Litzow, M. A., M. E. Hunsicker, N. A. Bond, B. J. Burke, C. J. Cunningham, J. L. Gosselin, E. L. Norton, E. J. Ward, and S. G. Zador. 2020. The changing physical and ecological meanings of North Pacific Ocean climate indices. Proc. Natl. Acad. Sci. 117(14):7,6657,671 (doi: https://doi.org/10.1073/pnas. 1921266117).

Macewicz, B. J., J. R. Hunter, N. C. H. Lo, and E. L. LaCasella. 2004. Fecundity, egg deposition, and mortality of market squid (Loligo opalescens). Fish. Bull. 102:306-327.

Mantua, N. J., S. R. Hare, Y. Zhang, J. M. Wallace, and R. C. Francis. 1997. A Pacific interdecadal climate oscillation with impacts on salmon production. Bull. Am. Meteorol. Soc. 78(6):1,069-1,080 (doi: https://doi. org/10.1175/1520-0477(1997)078<1069:API COW>2.0.CO;2).

Mueter, F. J., and M. A. Litzow. 2008. Sea ice retreat alters the biogeography of the Bering Sea continental shelf. Ecol. Appl. 18(2):309320 (doi: https://doi.org/10.1890/07-0564.1).

Navarro, M. 2018. As Alaskan waters warm, market squid extend their reach northward. Undark News and Features (avail. at https:// undark.org/2018/03/14/market-squid-alaskaclimate-change/).

Navarro, M. O., P. E. Parnell, and L. A. Levin. 2018. Essential market squid (Doryteu- 
this opalescens) embryo habitat: a baseline for anticipated ocean climate change. J. Shellf. Res. 37(3):601-614 (doi: https://doi. org/10.2983/035.037.0313).

Olson, J. M., and W. J. McNeil. 1967. Research on pink salmon at Little Port Walter, Alaska, 1934-64. U.S. Fish Wildl. Serv. Data Rep. 17, $301 \mathrm{p}$.

Pearcy, W. G., and A. Schoener. 1987. Changes in the marine biota coincident with the 198283 El Niño in the northeastern subarctic Pacific Ocean. J. Geophys. Res. 92:14,41714,428 (doi: https://doi.org/10.1029/ JC092iC13p14417)

Perretti, C. T., P. J. Zerofski, and M. Sedarat. 2016. The spawning dynamics of California market squid (Doryteuthis opalescens) as revealed by laboratory observations. J. Molluscan Stud. 82:37-42 (doi: https://doi. org/10.1093/mollus/eyv028).

Peterson, W., M. Robert, and N. Bond. 2015. The warm blob - conditions in the northeastern Pacific Ocean. PICES Press 23(1):36-38 (avail. at https://meetings.pices.int/publications/pices-press/volume23/issue1/PPJanuary2015.pdf\#page $=36$ ).

Portner, H. O. 2008. Ecosystem effects of ocean acidification in times of ocean warming: a physiologist's view. Mar. Ecol. 373:203-218 (doi: https://doi.org/10.3354/meps07768).

Reid, G. M. 1961. Stomach content analyses of troll-caught salmon in southeastern Alaska, 1957-58. U.S. Dep. Inter., Bur. Commer.
Fish., Spec. Sci. Rep.-Fish. 379, 8 p. (avail. at https://spo.nmfs.noaa.gov/sites/default/files/ legacy-pdfs/SSRF379.pdf).

Spies, I., K. M. Gruenthal, D. P. Drinan, A. B. Hollowed, D. E. Stevenson, C. M. Tarpey, and L. Hauser. 2019. Genetic evidence of a northward range expansion in the eastern Bering Sea stock of Pacific cod. Evolutionary Applic. 13(2):362-375 (doi: https://doi. org/10.1111/eva.12874).

Spratt, J. D. 1978. Age and growth of market squid, Loligo opalescens Berry, in Monterey Bay from statoliths. In C. W. Recksiek and H. W. Frey (Editors), Biological, oceanographic, and acoustic aspects of the market squid, Loligo opalescens Berry, p. 35-44. Calif. Dep. Fish Game Bull. 169, 185 p.

Tseng, Y., R. Ding, and X. Huang. 2017. The warm Blob in the northeast Pacific-the bridge leading to the 2015/16 El Niño. Environ. Res. Letters 12:054019 (doi: https://doi. org/10.1088/1748-9326/aa67c3).

Venrick, E. L., J. A. McGowan, D. R. Cayan, and T. L. Hayward. 1987. Climate and chlorophyll a: long-term trends in the central North Pacific Ocean. Science 238:70-72. (doi: https://doi.org/10.1126/science.238.4823.70).

Vojkovich, M. 1998. The California fishery for market squid (Loligo opalescens). Calif. Coop. Oceanic Fish. Invest., Calif. Market Squid Fish. Rep. 39:55-60 (avail. at http:// calcofi.org/publications/calcofireports/v39/ Vol_39_Vojkovich.pdf).
Wing, B. L. 1985. Salmon stomach contents from Alaska troll logbook program, 1977 1984. U.S. Dep. Commer., NOAA Tech. Memo. NMFS F/NWC-91, 43 p.

and R. W. Mercer. 1990. Temporary northern range extension of the squid Loligo opalescens in Southeast Alaska. Veliger 33:238-240.

Zeidberg, L. D. 2013. Doryteuthis opalescens, opalescent inshore squid. In R. Rosa, R. O'Dor, and G. J. Pierce (Editors), Advances in squid biology, ecology and fisheries, pt. I - myopsid squid, p. 159-204. Nova Biomed. N.Y., Nova Sci. Publ., Inc.

W. M. Hammer, N. P. Nezlin, and A. Henry. 2006. The fishery for California market squid (Loligo opalescens) (Cephalopoda: Myopsida), from 1981 through 2003. Fish. Bull. 104:46-59.

G. Isaac, C. L. Widmer, H. Neumeister, and W. F. Gilly. 2011. Egg capsule hatch rate and incubation duration of the California market squid, Doryteuthis (= Loligo) opalescens: insights from laboratory manipulations. Mar. Ecol. 32:468-479 (doi: https:// doi.org/10.1111/j.1439-0485.2011.00445.x). J. L. Butler, D. Ramon, A Cossio, K. L. Stierhoff, and A. Henry. 2012. Estimation of spawning habitats of market squid (Doryteuthis opalescens) from field surveys of eggs off Central and Southern California. Mar. Ecol. 33:326-336 (doi: https://doi. org/10.1111/j.1439-0485.2011.00498.x). 